\title{
Response of grower rabbits fed diet containing boiled sorrel (Hibiscus sabdariffa l.) Seed meal on performance growth characteristics \\ ${ }^{* 1}$ Aliyu, A. M., ${ }^{2}$ Duru, S. and ${ }^{2}$ Bawa, G. S. \\ ${ }^{\prime}$ National Agricultural Extension Research and Liaison Services, ABU, Zaria. \\ ${ }^{2}$ Department of Animal Science, Faculty of Agriculture, Ahmadu Bello University, Zaria. \\ Abstract \\ *Corresponding author: layi5821@gmail.com
}

The experiment was conducted to evaluate the performance of grower rabbits fed sorrel seed (Hibiscus sabdariffa L.) meal. Thirty grower rabbits were randomly allotted to five dietary treatments containing the control diet, raw seed diet and boiled sorrel seeds in already boiled water for 15, 30 and 45 minutes. Completely randomized design was used with six rabbits per treatment and two rabbits per replicate. Parameters evaluated were average feed intake, average weight gain, feed conversion ratio, final body weight, feed cost/kg gain and Mortality. The result of the experiment showed that there was significant difference $(P<0.05)$ in average daily feed intake but no significant $(P>0.05)$ differences in final body weight gain, daily weight gain, total feed intake, feed conversion ratio and feed cost $/ \mathrm{kg}$ gain of rabbits fed diet containing sorrel seeds boiled at varying boiling duration. Feed conversion ratio was better in rabbits fed the 30 minutes boiled sorrel seed based diet (6.28) compared to rabbits fed 45 minutes boiled sorrel seed based diet (7.69). The final weight increased as boiling duration increased but later declined as boiling duration increased to 45 minutes (1360.00, 1286.67, 1293.33, 1386.67 and 1306.00g/rabbit) respectively. Feed cost/kg gain value was lower in rabbits fed diet containing boiled sorrel seeds at 30 minutes $(<600.20)$ compared to other treatments. Based on the result of the study, it was therefore concluded that grower rabbits could tolerate up to $15 \%$ sorrel seed meal boiled for 30 minutes in their diets.

Keywords: Rabbits, Sorrel seed meal, Boiling and performance growth

\section{Introduction}

The huge animal protein deficit in the diet of Nigerians can be addressed by placing emphasis on the production of highly prolific and short cycle animal species such as rabbits (Oyawoye, 2002; Hasanat et al., 2006). Rabbits however, require a good balance dietary protein for their maximum performance. Conventional feed are short in supply, expensive and highly consumed by human in Nigeria. This constitutes a major setback to increased rabbit production in the country and calls for research into less conventional sources of protein for rabbit feeding. The use of unconventional feed ingredients in compounding livestock feed in order to reduce cost of production is documented in literature (Abeke, 2008 and Duru, 2010).
Non-conventional feedstuffs offer the best alternatives in our environment for reducing feed cost and therefore a reduction in the cost of meat productions (Dafwang et al., 2001). There is need to find alternative feed ingredients that can substitute for the more conventional feedstuff which is expensive and highly needed for human and industrial needs. Sorrel (Hibiscus sabdariffa) seed is an alternative feed resources that has been found to thrive on a wide range of tropical soil conditions, and can perform well on relatively poorer soil (Adanlawo and Ajibade, 2006). The seed contain high amount of protein, dietary fibre, and mineral such as phosphorus $(\mathrm{P})$, calcium $(\mathrm{Ca})$ and magnesium $(\mathrm{Mg})$ (Ismail et al., 2008). The seeds contain about $35.90 \%$ crude protein $(\mathrm{CP}), 10.14 \%$ ether 


\section{Response of grower rabbits fed diet containing boiled sorrel (hibiscus sabdariffa l.)}

extract (EE), $10.09 \%$ ash and $15-17 \%$ crude fibre (CF) (Dashak and Nwanegbo, 2002). Kwari et al. (2011) also reported raw sorrel seeds to contain $5.18 \%$ arginine, $16.5 \% \mathrm{CF}$, $13.5 \%$ EE and $38.57 \% \mathrm{CP}$ while Abdu et al. (2008) reported $23.46 \%$ CP value. However, Nyameh et al. (2012) reported that boiled sorrel seeds contain $22.84 \% \mathrm{CP}$, $8.50 \% \mathrm{CF}, 6.50 \% \mathrm{EE}, 6.50 \%$ ash, $45.66 \%$ NFE and $91.70 \%$ DM. while Maikano et al. (2014) reported a value of $21.84 \% \mathrm{CP}$, $3.60 \%$ CF, 5.85\% EE, 5.39\% ash, $90.40 \%$ DM, 53.72\% NFE, $1.12 \% \mathrm{Ca}$ and $0.56 \% \mathrm{P}$, respectively.

\section{Materials and methods Experimental site}

The experiment was carried out at the Rabbit Unit of the Department of Animal Science Teaching and Research Farm, Ahmadu Bello University, Zaria. Zaria is within the northern guinea savanna zone of Nigeria, with Latitude $11^{0} 09^{\prime} 01.78 \mathrm{ON}$ and Longitude $7^{0} 39^{\prime} 14.79 \mathrm{OE}$ at an altitude of $671 \mathrm{~m}$ above sea level (Ovimaps, 2015).

Sources of rabbits and sorrel seeds

The rabbits of mixed breeds and sexes aged
$7-8$ weeks were sourced from rabbit farms within Zaria metropolis. The sorrel seeds and other ingredients were purchased from an open market in Sabon Gari, Zaria.

\section{Processing of sorrel seeds}

The raw sorrel seeds were sorted to ensure cleared grains. The method adopted by Ari et al. (2012) was used for processing. The cleaned sorrel seeds were poured into $20 \mathrm{~L}$ of already boiled water per batch of $10 \mathrm{~kg}$ at $100^{\circ} \mathrm{C}$ i.e. in ratio of $2: 1$ at different boiling duration of $0,15,30$ and 45 minutes, respectively. The products were then sun dried by spreading on trays until well dried (at least $75-80 \% \mathrm{DM}$ ), after which it was milled, bagged and stored for experimental diet formulation purpose.

\section{Experimental diet}

Five experimental diets were formulated to meet the requirements of rabbits according to NRC (1994). These include T1 (Sorrel seed free diet as control); T2 (Raw sorrel seeds diet); T3 (Diet containing Sorrel seeds boiled at 15 minutes); T4 (Diet containing Sorrel seeds boiled at 30 minutes) and T5 (Diet containing Sorrel seeds boiled at 45 minutes).

Table 1: Composition of experimental diets

\begin{tabular}{|c|c|c|c|c|c|}
\hline \multirow[b]{2}{*}{ Ingredients (Kg) } & \multicolumn{5}{|c|}{ Duration of boiling of sorrel seeds (minutes) } \\
\hline & Control & Raw (0) & 15 & 30 & 45 \\
\hline Maize & 45.05 & 36.98 & 38.09 & 38.12 & 38.33 \\
\hline Soya bean cake & 12.45 & 5.52 & 4.41 & 4.38 & 4.17 \\
\hline Boiled sorrel seed meal & 0.00 & 15.00 & 15.00 & 15.00 & 15.00 \\
\hline Groundnut Haulms & 40.00 & 40.00 & 40.00 & 40.00 & 40.00 \\
\hline Bone meal & 2.00 & 2.00 & 2.00 & 2.00 & 2.00 \\
\hline Table Salt & 0.25 & 0.25 & 0.25 & 0.25 & 0.25 \\
\hline Premix & 0.25 & 0.25 & 0.25 & 0.25 & 0.25 \\
\hline Total & 100.00 & 100.00 & 100.00 & 100.00 & 100.00 \\
\hline \multicolumn{6}{|l|}{ Calculated Analysis } \\
\hline Crude protein $(\%)$ & 18.41 & 18.99 & 18.60 & 18.59 & 18.52 \\
\hline Crude fibre $(\%)$ & 6.82 & 8.62 & 8.55 & 8.55 & 8.54 \\
\hline Ether Extract $(\%)$ & 5.39 & 5.76 & 5.73 & 5.73 & 5.72 \\
\hline Metabolizable energy (Kcal/kg) & 2852 & 2767 & 2779 & 2779 & 2781 \\
\hline Calcium $(\%)$ & 0.67 & 0.68 & 0.68 & 0.68 & 0.68 \\
\hline Available Phosphorus (\%) & 0.42 & 0.47 & 0.47 & 0.47 & 0.47 \\
\hline Lysine $(\%)$ & 0.83 & 0.81 & 0.78 & 0.78 & 0.78 \\
\hline Methionine + cysteine $(\%)$ & 0.72 & 0.67 & 0.66 & 0.66 & 0.65 \\
\hline $\mathrm{Ca}: \mathrm{P}$ & 1.6 & 1.4 & 1.4 & 1.4 & 1.4 \\
\hline Cost/kg diet $(\AA)$ & 100.21 & 95.41 & 95.55 & 95.56 & 95.58 \\
\hline
\end{tabular}




\section{Aliyu, Duru and Bawa}

Experimental design and management of animals

Thirty weaner rabbits of mixed breeds and sexes aged 7-8 weeks were randomly allotted into five treatments with three replicates per treatment; each replicate had two rabbits in a completely randomized design. Before the commencement of the experiment, they were dewormed using ivermectin ${ }^{\circledR}$ dewormer. The rabbits were housed in galvanized wire cages of $40 \times 60 \times$ $60 \mathrm{~cm}$ dimension. Each cage was equipped with a small rubber bowl drinker and a clay/earthen pot feeder. Feed and clean water were supplied ad-libitum for a period of 56 days after an adjustment period of a week.

\section{Data collection}

Feed offered and left over were weighed to determine feed intake of the animals. After the initial weight, weekly weights were taken. These records were used to monitor and determine the performance parameters in terms of average feed intake (AFI), average weight gain (AWG), feed conversion ratio (FCR), final body weight and feed cost $/ \mathrm{kg}$ gain. Mortality was also recorded as they occur.

\section{Results}

Proximate compositions of raw and boiled sorrel seeds

The Crude Protein (CP) of raw and boiled seeds $(15,30$ - and 45 - minutes durations) were $21.75,27.88,28.00$ and 29.22, respectively. The $\mathrm{CP}$ of boiled sorrel seeds (BSS) was significantly higher $(\mathrm{P}<0.05)$ than the raw and its value increases as the duration of boiling increases. The Crude Fibre (CF) levels were between 6.50\%$14.50 \%$. It was observed in this study that the processed (boiled) seeds were statistically the same $(\mathrm{P}<0.05)$ having higher $\mathrm{CF}$ than the unprocessed (raw) seeds. The Ether Extract (EE) level in raw seeds was significantly $(\mathrm{P}<0.05)$ higher than the values for BSS at different durations. Ash values ranged from $5.30 \%-6.18 \%$ for raw and boiled seeds at different durations. The Nitrogen Free Extract (NFE) which represent the readily available carbohydrates in the sorrel seed were 39.22 , $38.36,41.80$ and 40.36 in the raw and boiled seeds at different durations, respectively.

Table 2: Proximate composition of raw and boiled sorrel seed at different durations

\begin{tabular}{lclllll}
\hline & \multicolumn{7}{c}{ Duration of boiled sorrel seed (minutes) } & & \\
\cline { 2 - 7 } Parameters (\%) & Raw(0) & 15 & 30 & 45 & SEM & LOS \\
\hline Dry Matter & 93.50 & 90.55 & 90.40 & 90.15 & 1.78 & NS \\
Crude Protein & $21.75^{\mathrm{d}}$ & $27.88^{\mathrm{c}}$ & $28.00^{\mathrm{b}}$ & $29.22^{\mathrm{a}}$ & 0.52 & $*$ \\
Crude Fiber & $6.50^{\mathrm{b}}$ & $13.25^{\mathrm{a}}$ & $12.80^{\mathrm{a}}$ & $14.50^{\mathrm{a}}$ & 1.86 & $*$ \\
Ether Extract & $26.79^{\mathrm{a}}$ & $14.33^{\mathrm{b}}$ & $12.10^{\mathrm{bc}}$ & $10.45^{\mathrm{c}}$ & 1.21 & $*$ \\
Ash & 5.74 & 6.18 & 5.30 & 5.47 & 0.22 & $\mathrm{NS}$ \\
Nitrogen Free Extract & 39.22 & 38.36 & 41.80 & 40.36 & 0.98 & $\mathrm{NS}$ \\
\hline
\end{tabular}

abc: means with different superscript on the same row differ significantly at $p<0.05$

SEM: standard error of mean; LOS: level of significance; NS: not significant

Performance of grower rabbits fed boiled sorrel seed meal based diet

There were no significant differences $(\mathrm{P}>0.05)$ in all performance parameters measured except for total and average daily feed intake which were reduced significantly $(\mathrm{P}<0.05)$ as the duration of boiling increased. Rabbits fed control, raw and 15 minutes based diets were statistically the same as compared to rabbits on 30 and 45 minutes based diets in terms of daily feed intake. It was observed that rabbits fed the 30 minutes BSS based diet had the lowest average daily feed intake, highest weight gain, the least FCR and feed cost $/ \mathrm{kg}$ weight gain. 
Response of grower rabbits fed diet containing boiled sorrel (hibiscus sabdariffa l.)

Table 3: Effect of different duration of boiled sorrel seed meal on performance of grower rabbits

\begin{tabular}{llllllll}
\hline & \multicolumn{7}{c}{ Duration of boiled sorrel seed (minutes) } \\
\cline { 2 - 8 } Parameters & Control & Raw (0) & 15 & 30 & 45 & SEM & LOS \\
\hline Initial body wt (g/rabbit) & 853.33 & 800.00 & 813.33 & 876.67 & 855.00 & 48.83 & $\mathrm{NS}$ \\
Final body wt (g/rabbit) & 1360.00 & 1286.67 & 1293.33 & 1386.67 & 1306.00 & 85.91 & $\mathrm{NS}$ \\
Average daily wt gain (grabbit) & 9.05 & 8.69 & 8.57 & 9.11 & 8.07 & 0.90 & $\mathrm{NS}$ \\
Total feed intake (g) & $3476.48^{\mathrm{a}}$ & $3517.36^{\mathrm{a}}$ & $3587.36^{\mathrm{a}}$ & $3178.56^{\mathrm{b}}$ & $3265.92^{\mathrm{b}}$ & 129.92 & $*$ \\
Average daily feed (g) & $62.08^{\mathrm{a}}$ & $62.81^{\mathrm{a}}$ & $64.06^{\mathrm{a}}$ & $56.76^{\mathrm{b}}$ & $58.32^{\mathrm{b}}$ & 2.32 & $*$ \\
intake (g/rabbit) & & & & & & & \\
Feed conversion ratio & 6.87 & 7.28 & 7.61 & 6.28 & 7.69 & 0.73 & $\mathrm{NS}$ \\
Feed cost per kg $(\Sigma)$ & 100.21 & 95.41 & 95.55 & 95.56 & 95.58 & & $\mathrm{NA}$ \\
Feed cost/kg gain & 688.17 & 694.84 & 727.28 & 600.20 & 735.82 & 69.61 & $\mathrm{NS}$ \\
Mortality (\%) & 0.00 & 0.00 & 0.00 & 0.00 & 0.33 & 0.15 & $\mathrm{NS}$ \\
\hline abc: means with different superscript on the same row differ significantly at p<0.05 & & & &
\end{tabular}

Discussions

\section{Proximate composition of raw and boiled} sorrel seed

The higher Crude Protein (CP) level of the BSS may be attributed to the processing method. Similar result was observed by Akinmutimi (2001) who subjected legumes seeds to moist-heating and reported a slight increase in the CP levels of the feed. The Crude Fibre (CF) levels of BSS were higher than the raw sorrel seeds. These values obtained were slightly lower to the values reported by Samy (1999). The Ether Extract (EE) levels were within the range given by FAO (1997). This is non-comparable with the report of Duwa et al. (2012) that higher level of EE in the BSS could be attributed to the decrease in the non-lipid component of the sorrel seeds during cooking. The ash value of $5.74 \%$ for raw seeds in this study agrees with the findings of Ari et al. (2013) who reported that crushed seeds of sorrel ranged from 5.39-6.94\% but below the value of $10.09 \%$ reported by Dashak and Nwanegbo, 2002. The boiled seeds at different boiling duration observed fell within the range $(5.39-6.50 \%)$ reported by Nyameh et al. (2012), Maikano et al.
(2014). The lower levels of the NFE in the BSS may be due to the high loss of NFE in water during boiling as previously reported by Samy (1999). This is not in line with the result obtained for this study. The results in the present study showed that boiled seeds could also have high NFE values as observed in 30 and 45 minutes of boiling.

Performance of grower rabbits fed boiled sorrel seed meal

The various diets fed to the rabbits showed no significant differences. Rabbits that performed best were those fed 30 minutes duration of boiled sorrel seed meal (BSSM) because it showed the highest weight gain, the best feed conversion ratio (FCR) despite having the lowest feed intake. This can be an indication that the rabbits were able to utilize and convert feed to gain. The above result was in line with the result reported by (Kaga 2013) when Delonix regina seeds cooked at different duration were fed to rabbits. Mortality of $0.33 \%$ was only recorded for 45 minutes $\mathrm{BSS}$ diet.

The FCR of rabbits fed 30 minutes BSS diet was the best although there were nonsignificant $(p>0.05)$ differences when compared with control, raw (0), 15- and 45- 
minutes boiling duration. This agreed with the reports of (Musa and Ogbadoyi, 2012) who stated that boiling reduces the level of anti-nutrients and toxic substances with retention of most micro-nutrients in amount sufficient to meet animal's dietary requirement but boiling beyond 30 minutes reduces B-carotene levels in seeds. Despite the anti-nutrients present in the raw seed based diet, they performed better than 45 minutes based diet. This result agreed with the findings of Halimatul et al. (2007) who reported that the quality of two differently processed (dried and boiled) roselle seed powder are similar and affect performance significantly when the seeds were boiled at $100^{\circ} \mathrm{C}$ for 30 minutes. Therefore, the antinutrient of raw roselle seed might not affect feed digestibility and biological value.

\section{Conclusion and Recommendations}

Based on this experiment, the highest value for final weight and best value for FCR were obtained from rabbits fed 30 minutes duration of boiled sorrel seed meal (BSSM) based diet despite showing no significant difference. It was observed that rabbits could tolerate raw sorrel and BSSM up to 30 minutes duration in their diet without negatively affecting performance parameters. Higher duration of boiling beyond 45 minutes resulted in a decline in performance of the rabbits. This was attributed to the fact that prolonged boiling reduces B-carotene levels in seeds or leaching and denaturation of protein in the samples. Boiling of sorrel seeds for 30 minutes was recommended as the optimum duration if boiling method is adopted.

\section{References}

Abdu, S. B., Adegoke, T. F., Abdulrasheed, M., Duru, S., Yashim, S. M. and Jokthan, G. E. 2008. Effect of cooking duration on chemical composition of Roselle
Seed. In: Bawa, G.S., Akpa, G.N., Jokthan, G.E., Kabir, M. and Abdu, S.B. (Editions) $13^{\text {th }}$ Proceedings of the Animal Science Association of Nigeria (ASAN) at A.B.U Zaria, pp521-523.

Abeke, F. O. 2008. Fibre in poultry diet concern and options, In Proceeding of the $33^{\text {rd }}$ Annual Conference of the Nigerian Society of Animal Production held at College of Agricultural Science, Olabisi Onabanjo University, Ayetoro, Ogun State, Nigeria. Pp 409-411.

Adanlawo, I. G. and Ajibade, V. A. 2006. Nutritive value of two varieties of rosella (Hibiscus sabdariffa) calyces soaked with wood ash. Pakistan Journal of Nutrition, 5(6): 555-557.

Akinmutimi, A. H. 2001. Soaked and toasted Lima beans (Phaseolus lunatus) in broiler chickens diets: Effects on haematological parameters and blood chemistry. In: C.O. Ubosi, A. Kibon, I.D. Kwari, J.U. Igwebuike, I.D. Mohammed, N.K. Alade, F.I. Abbator and S.B. Adamu (Eds) 6th Annual Conference of the Animal Science Association of Nigeria, University of Maiduguri, Maiduguri Convocation Square, pp: 48-49.

Ari, M. M., Ayanwale, B. A., Adama, T. Z. and Olatunji, E.A. 2012. Effect of Different Fermentation Methods on Growth Indices and Serum Profile of Broiler Chickens. Journal of Biology, Agriculture and Healthcare, 2(5):78-86.

Ari, M. M., Ogah, D. M., Hassan, I. D., Musa-Azara, I. S., Yusuf, N. D. and Alu, S. E. 2013. Effect of utilization of crushed, boiled and fermented roselle seeds (Hibiscus 
Response of grower rabbits fed diet containing boiled sorrel (hibiscus sabdariffa l.)

sabdariffa L.) on the performance of broiler chickens. British Biotechnology Journal, 4(1): 4-11. www.sciencedomain.org.

Dafwang, I., Ikani, E. J., Chikwendu, D. O., Adeshinwa, A. O. K., Annale, A. I. and Iwuanyanwu, I. E. J. 2001. An assessment of adoption of non-conventional feedstuff. Poultry and Rabbit Research, (3): 3 -5 .

Dashak, D. A. and Nwanegbo, V. 2002. Chemical composition of the seeds of calyxes of Hibiscus sabdariffa grown in Jos North LGA of Plateau. Journal of Natural Sciences, 5: 32-34.

Duru, S. 2010. Effects of different types of rice offal with or without enzyme supplementation on the performance of broiler chickens.A PhD Thesis, Department of Animal science, Ahmadu Bello University, Zaria.

Duwa, H., Oyawoye, E. O. and Njidda, A. A. 2012. Effect of Processing Methods on the Utilization of Sorrel Seed Meal by Broilers. Pakistan Journal of Nutrition, 11(1): 38-46.

FAO (Food and Agriculture Organization) 1997. In: The Rabbit: Husbandry, Health and Production. David Lubin Memorial Library cataloguing in publication data, pp. 205.

Halimatul, S. M. M., Amin, I., Mohd-Esa, N., Nawalyah, A. G. and SitiMuskinah, M. 2007. Protein Quality of Roselle (Hibiscus, sabdariffa L.). Asian Food Journal, 14(2): 131-140.

Hasanat, M. S., Hossain, M. E., Mostari, M. P. and Hossain, M. A. 2006. Effect of concentrate supplementation on growth and reproductive performance of rabbit under rural condition. Bang. Journal of Veterinary Medicine, 4(2):129-132.

Ismail, A. E., Ikram, H. K. and Nazri, H. S. M. 2008. Roselle (Hibiscus sabdariffa L.) seeds. Nutritional composition, protein quality and health benefit, Food, $1-16$.

Kaga, I. B. 2013. Growth and Haematological effects on rabbits fed Delonix regia seeds diets. Biological System Open Access. 2:121.

Kwari, I. D., Igwebuike, J. U., Mohammed, I. D. and Diarra, S. S. 2011. Growth, haematology and serum biochemistry of broiler chickens fed raw or differently processed sorrel (Hibiscus sabdariffa) seed meal in a semi arid environment. International Journal of Science and Nature, 2(1): $22-27$.

Maikano, M. A., Danlami, M. O., Idris, D. H., Suleiman, M. A., Nuhu, D. T. and Samuel, E. A. 2014. Effects of utilization of crushed, boiled and fermented Roselle seed (Hibiscus sabdariffa) on the performance of broiler chickens. British Biotechnology Journal, 4(1): $21-29$.

Musa, A. and Ogbadoyi, E. O. 2012. Effect of processing methods on some micro nutrients, anti nutrients and toxic substances in Hibiscus sabdariffa. Asian journal of biochemistry, 7(2):63-79.

National Research Council. 1994. Nutrient Requirements of Rabbits. National Academic of Science, Washington, DC, USA.

Nyameh, J., Ribanre, A. J., Alabi, J., Mufwa, B. J. and Gyau, A. M. 2012. Effect of Processing on the 


\section{Aliyu, Duru and Bawa}

Performance and Carcass Yield of Broilers Fed Differently Processed Sorrel (Hibiscus sabdariffa). Journal of Agriculture and Veterinary Sciences, 4: 1-4.

Ovimaps. 2015. Ovi location map; Ovi earth imagery date; July $30^{\text {th }}, 2015$.

Oyawoye, E. O. 2002. Eradication of Animal Protein Malnutrition in Nigeria Through the Production and Consumption of Micro Livestock. A task that must be done. $28^{\text {th }}$ Inaugural Lecture, ATBU, Bauchi.
Samy, J. C. 1999. Proximate analysis, In: Christie, B.R. (Ed). The Handbook of plant Science in Agriculture, CRC Press, Inc. BocaRaton, Flourida.

Received: $22^{\text {nd }}$ April, 2019

Accepted: 25 July, 2019 